\title{
Targeting CAIX with small molecules
}

Citation for published version (APA):

Parvathaneni, N. K. (2017). Targeting CAIX with small molecules: design, synthesis and biological efficacy. [Doctoral Thesis, Maastricht University]. Datawyse / Universitaire Pers Maastricht. https://doi.org/10.26481/dis.20171212nkp

Document status and date:

Published: 01/01/2017

DOI:

10.26481/dis.20171212nkp

Document Version:

Publisher's PDF, also known as Version of record

\section{Please check the document version of this publication:}

- A submitted manuscript is the version of the article upon submission and before peer-review. There can be important differences between the submitted version and the official published version of record.

People interested in the research are advised to contact the author for the final version of the publication, or visit the DOI to the publisher's website.

- The final author version and the galley proof are versions of the publication after peer review.

- The final published version features the final layout of the paper including the volume, issue and page numbers.

Link to publication

\footnotetext{
General rights rights.

- You may freely distribute the URL identifying the publication in the public portal. please follow below link for the End User Agreement:

www.umlib.nl/taverne-license

Take down policy

If you believe that this document breaches copyright please contact us at:

repository@maastrichtuniversity.nl

providing details and we will investigate your claim.
}

Copyright and moral rights for the publications made accessible in the public portal are retained by the authors and/or other copyright owners and it is a condition of accessing publications that users recognise and abide by the legal requirements associated with these

- Users may download and print one copy of any publication from the public portal for the purpose of private study or research.

- You may not further distribute the material or use it for any profit-making activity or commercial gain

If the publication is distributed under the terms of Article $25 \mathrm{fa}$ of the Dutch Copyright Act, indicated by the "Taverne" license above, 
Summary 
Hypoxia is a salient feature in many solid tumors and arises due to an inadequate and immature vascular supply resulting in a decreased delivery of oxygen and nutrients. These hypoxic regions show resistance towards conventional treatment modalities such as radio- and chemotherapy and are associated with poor survival. To survive these hostile microenvironmental stress tumor cells have to adapt, which can partly be mediated via stabilization of the hypoxia-inducible factor 1 alpha (HIF-1 $\alpha)$. Under hypoxic conditions HIF-1 $\alpha$ dimerizes with HIF-1 $\beta$ and binds to the hypoxia responsive element (HRE) in the promoter regions to enhance the expression of many target genes, one of them being carbonic anhydrase IX (CAIX). CAIX is a transmembrane enzyme, which is involved in maintaining the $\mathrm{pH}$ balance between an acidic extracellular and an alkaline intracellular environment by reversible hydration of carbon dioxide to bicarbonate and a proton. The specific overexpression of CAIX in hypoxic solid tumors and minimal/no expression in normal tissues makes CAIX a good biomarker for endogenous hypoxia but also an attractive therapeutic target for caner therapy. Therefore, the aim of this thesis was to target CAIX using various dual target drugs combined with radiosensitizers, cytotoxic drugs and bio-reducible drugs. In this thesis several CAIX targeting approaches have been investigated.

First we discussed Structure Activity Relationship (SAR) studies on nitroimidazoles and their derivatives known as anti-anaerobic agents and hypoxic cell sensitizers (Chapter 2). SAR studies demonstrated that nitroimidazole derivatives with higher reduction potentials might serve as good hypoxic cell sensitizers. Altering parameters such as aqueous solubility and electron affinity would also help in the development of an optimimal radiosensitizer with minimal side effects.

Since nitroimidazoles are good hypoxic cell sensitizers, we have designed several dual target compounds existing out of a combination of a nitroimidazole and a carbonic anhydrase IX inhibitory moiety (Chapter 3). It has been shown that extracellular acidity limits the uptake of weak basic chemotherapeutic drugs, such as doxorubicin, and thereby decreases its efficacy. We hypothesized that combining these nitroimidazole moieties with a sulfonamide/sulfamide/sulfamate to target CAIX results in a decrease in extracellular acidosis and sensitizes hypoxic tumors to chemoand radiotherapy. Previously, our group has shown that the sulfamide-based derivative 7 enhanced the therapeutic efficacy of irradiation in a CAIX dependent manner with a sensitization enhancement ratio (SER) of 1.50, which is higher than several clinically tested radiosensitizers such as misonidazole and nimorazole. Chemosensitization efficacy was observed upon combination of 7 with doxorubicin in HT29 tumor-bearing mice (Chapter 3). X-ray crystal structure of hCAII/7 shows the binding of derivative 7 to the active site of the enzyme and strengthens our data that CA inhibition reduces extracellular acidification, thereby sensitizing tumors towards chemo- and radiotherapy.

A similar dual target approach may be exploitable to deliver cytotoxic drugs towards CAIX expressing cells, resulting in a specific tumor targeted delivery and consequently reduced normal tissue toxicity. Chapter 4 describes the design and synthesis of new series of dual target compounds combining several anti-cancer 
drugs, including the chemotherapeutic agents chlorambucil, tirapazamine, temozolamide, two-ataxia telangiectasia and Rad3-related protein inhibitors (ATRi), and the anti-diabetic biguanide agent phenformin. Only one compound, i.e. an ATRi derivative, showed a higher efficacy in combination with radiation in CAIX overexpressing cells as compared to cells lacking CAIX expression. Nevertheless, the efficacy of this compound for CAIX expressing cells might not solely depend on binding of the compound to CAIX, since all of the synthesized derivatives exhibit a low binding affinity to CAIX and other human carbonic anhydrase isoforms. The hypothesis that these dual target compounds specifically affect CAIX expressing tumor cells was not confirmed, but targeting CAIX with combination of cytotoxic drugs continues to be an interesting area for future drug development.

The significance of hypoxia in resistance to cytotoxic drugs has regained interest in targeting hypoxic tumors, since bio-reducible drugs and hypoxia-activated prodrugs proved their success to treat these tumors. Chapter 5 describes the design and synthesis of various bio-reducible nitroimidazole derivatives, nitrogen mustard alkylating agents and N-oxide derivatives combined with a carbonic anhydrase IX inhibiting moiety. All these compounds showed weak to moderate inhibition profiles towards several tested CA isoforms. We have observed that different substitutions and linkers within the same family of compounds influence the binding capacity to CAIX. For example derivatives $\mathbf{1 7}$ and $\mathbf{2 0}$ belong to same family, but have a different linker and substitution of the aromatic ring, leading to a different binding capacity towards CAIX. This suggests that there is an urgent need for better understanding the interaction of CAIX inhibitors with the active site of the protein.

To expand our study on bio-reducible drugs, Chapter 6 describes the design and synthesis of 2-, 5-nitroimdazole and nitrogen mustards combined with carbonic anhydrase IX inhibitors by a carbamate linker. The 2-nitroimidazole derivative 1b revealed cytotoxicity in HT29 and HCT116 cell lines and might be explain by the higher reduction potential of 2-nitroimidazoles compared to 5-nitroimidazoles, since our results did show no cytotoxicity of the 5-nitroimidazole derivatives. The nitrogen mustard derivatives was effective, but in a highly cell dependent manner, being effective under normoxia and anoxia only in the HCT116 cell line (derivative $3 \mathbf{b}$ ), whereas derivative $3 \mathbf{c}$ did not show any cytotoxicity, which might be explained by substitution of the aromatic sulfonamide on the nitrogen mustard. Our future studies aim to optimize the radiosensitizing efficacy of $\mathbf{2 b}$ and $\mathbf{2 c}$ and further explore the cytotoxic properties of $\mathbf{1 b}$. Our results however stress the need for SAR studies on bio-reducible drugs combined with carbonic anhydrase IX moieties to guide the development of new cytotoxic anti-cancer drugs.

In conclusion, this thesis showed that the dual target nitroimidazole combined with CAIXi increases the efficacy of standard treatment modalities such as chemo- and radiotherapy. Targeting CAIX with combination of cytotoxic drugs continues to be an interesting approach to target hypoxic tumors in future. Bio-reducible drugs with higher reduction potentials would serve as potential cytotoxic agents to hypoxic tumors thereby decreasing the normal tissue toxicity. However SAR studies, docking 
and molecular modeling studies are needed for the design of CAIX inhibitors with higher selectivity. 